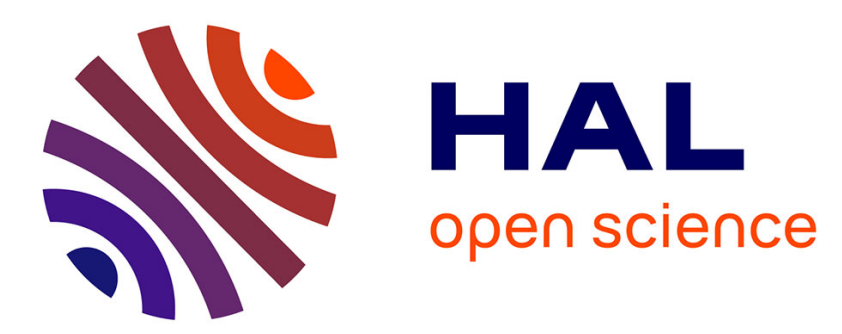

\title{
Chemical composition, digestibility and in situ degradability of narbon vetch grain and straw grown in a Mediterranean region
}

Miltiades Hadjipanayiotou

\section{- To cite this version:}

Miltiades Hadjipanayiotou. Chemical composition, digestibility and in situ degradability of narbon vetch grain and straw grown in a Mediterranean region. Annales de zootechnie, 2000, 49 (6), pp.475478. 10.1051/animres:2000137 . hal-00889913

\section{HAL Id: hal-00889913 https://hal.science/hal-00889913}

Submitted on 1 Jan 2000

HAL is a multi-disciplinary open access archive for the deposit and dissemination of scientific research documents, whether they are published or not. The documents may come from teaching and research institutions in France or abroad, or from public or private research centers.
L'archive ouverte pluridisciplinaire HAL, est destinée au dépôt et à la diffusion de documents scientifiques de niveau recherche, publiés ou non, émanant des établissements d'enseignement et de recherche français ou étrangers, des laboratoires publics ou privés. 


\title{
Chemical composition, digestibility and in situ degradability of narbon vetch grain and straw grown in a Mediterranean region
}

\author{
Miltiades HaDJIPANAYIOTOU* \\ Agricultural Research Institute, 1516 Nicosia, PO Box 22016, Cyprus
}

(Received 22 July 1999; accepted 18 September 2000)

\begin{abstract}
Apparent digestibility of narbon vetch (Vicia narbonensis) grain and straw were measured using four Chios wether sheep per foodstuff. In another trial, the in situ degradation of narbon vetch grain and straw in the rumen of three Chios ewes were measured. The crude protein $(\mathrm{CP})$ and in vitro organic matter digestibility values were 23.4 and 87.6 for narbon vetch grain and 7.4 and $44.8 \%$ for narbon vetch straw. In vivo apparent digestion coefficients of dry matter (DM), organic matter (OM) and $\mathrm{CP}$ were for narbon vetch grain 78,80 and $75 \%$ and for narbon vetch straw 44,42 and $47 \%$, respectively. The effective degradability (outflow rate $0.05 \cdot \mathrm{h}^{-1}$ ) for narbon vetch grain and straw were for CP 74 and 31\% (corrected for microbial contamination) and for DM 64 and 36\%, respectively.

digestibility / degradability / chemical composition / narbon vetch grain / narbon vetch straw

Résumé - Composition chimique, digestibilité et dégradabilité in situ de la paille et des grains de vesce de Narbonne cultivée dans une région méditerranéenne. La digestibilité apparente et la dégradation dans le rumen de la paille et des grains de vesce de Narbonne (Vicia narbonensis) ont été mesurées, respectivement, sur huit moutons de Chio castrés (4 par aliment) et trois brebis de Chio munies d'une canule du rumen. Les valeurs de protéines brutes et de digestibilité in vitro ont été de 23,4 et $87,6 \%$ pour les grains et 7,4 et $44,8 \%$ pour la paille. Les coefficients de digestibilité apparente in vivo de la matière sèche, de la matière organique et des protéines brutes ont été pour les grains de vesce de 78, 80 et $75 \%$ et pour la paille de 44,42 et $47 \%$, respectivement. La dégradabilité effective (taux de sortie de $0,05 \cdot \mathrm{h}^{-1}$ ) des protéines brutes a été de 74 et $31 \%$ (prise en compte de l'erreur liée à la contamination microbienne) et celle de la matière sèche de 64 et $36 \%$ pour les grains et la paille de vesce, respectivement.
\end{abstract}

digestibilité / dégradabilité / composition chimique / grains de vesce de Narbonne / paille de vesce de Narbonne

* Correspondence and reprints

Tel.: 3572 305101; fax: 3572 316770; e-mail: miltos @ arinet.ari.gov.cy 


\section{INTRODUCTION}

Many species of legumes are potentially adapted to the dryland agricultural regions of Mediterranean countries. Narbon bean is a grain and forage legume native to the alkaline soils and low rainfall areas of the Mediterranean and the Middle East. Narbon requires lower rainfall than chickpeas, faba beans and lentils, and may be proven a better legume alternative in rotation systems [7].

The importance of evaluating the nutritional worth of ruminant animal feedstuffs taking into consideration and their protein ruminal metabolism has long been recognized [2]. The present paper reports data on the chemical composition and digestibility of narbon vetch grain and straw, as well as their effective dry matter (DM) and crude protein $(\mathrm{CP})$ degradability.

\section{MATERIALS AND METHODS}

\subsection{In vivo digestibility}

Eight three year old Chios wether sheep of approximately $77 \mathrm{~kg}$ live weight were used. The animals were housed in metabolism crates designed for the separate collection of urine and faeces. All animals were offered a basic ration for 30 days. The basic ration was composed of $400 \mathrm{~g}$ concentrate mixture (11.3 MJ ME $\cdot \mathrm{kg}^{-1}$ and $140 \mathrm{~g} \mathrm{CP}$, as fed basis) and $200 \mathrm{~g}$ barley hay. During the first 9-12 days the basic ration was group offered whereas, during the rest period animals were transferred to metabolic crates and were offered individually the mixture and hay from separate feed containers. The concentrate mixture was composed $\left(\mathrm{g} \cdot \mathrm{kg}^{-1}\right)$ of 821 barley grain, 107 soybean meal, 50 wheat bran, 3 dicalcium phosphate, 13 limestone, 4 salt and 2 vitamin trace element mixture. The vitamin trace element mixture supplied $6000 \mathrm{IU}$ vitamin $\mathrm{A}, 600 \mathrm{IU}$ vitamin $\mathrm{D}_{3}$, $8.5 \mathrm{IU}$ vitamin $\mathrm{E}, 25 \mathrm{mg} \mathrm{Mn}, 1.5 \mathrm{mg} \mathrm{I}$, $45 \mathrm{mg} \mathrm{Zn}, 30 \mathrm{mg} \mathrm{Fe}, 1.5 \mathrm{mg}$ Co and $60 \mathrm{mg}$
Mg per kg mixture as fed. Following the determination of the digestibility of the basic ration the animals were randomly divided into two groups of four animals each, and each group was allocated to one of the foodstuffs on test. Grain and straw on test were added to the basic ration at the rate of 300 and $400 \mathrm{~g} \cdot \mathrm{head}^{-1}$, respectively. There were at least two week adaptation period, which were followed by one-week collection period. The difference method [8] was used to calculate digestion coefficient of the foodstuffs on test. Foodstuffs on test were from two-cycle rotation legume cereal grain grown under non-irrigated conditions at Athalassa. Individual feed intake was recorded daily. The animals had free access to water. Collection, processing and analysis of feed and faecal samples were made as outlined by Hadjipanayiotou et al. [5]. Other chemical analyses on feeds and faeces were made on dried $\left(60^{\circ} \mathrm{C}\right)$ samples ground to pass a $1 \mathrm{~mm}$ sieve [1]. In vitro digestibility of foodstuffs was measured following the Tilley and Terry [11] procedure.

\subsection{In situ degradability}

The degradability in the rumen of narbon vetch grain and straw was determined using three rumen fistulated Chios ewes. Nylon material with $36 \mu \mathrm{m}$ pore size (HSO 13, Henry Simon Ltd, PO Box 31, Stockport, England) was used for the bags. The dimensions of the bags were $140 \times 90 \mathrm{~mm}$, and about 5 (grain) or 3 (straws) g dry sample were placed in each bag. Bags were then anchored from the top of the cannula using $25 \mathrm{~cm}$ nylon tubing. Bags with grain were incubated in the rumen for 2, 5, 8, 24 and $48 \mathrm{~h}$, and those with straw for $8,16,24,48$ and $64 \mathrm{~h}$.

The procedures used for bags and sample processing, chemical analysis and calculation of effective DM and CP degradability values were those outlined by Orskov [10] and Hadjipanayiotou et al. [6]. Fistulated animals were offered daily $0.5 \mathrm{~kg}$ concentrate 
(160 g CP per kg DM) and $0.5 \mathrm{~kg}$ of barley hay. Effective $\mathrm{CP}$ degradability values were corrected for bacterial contamination using the equation of Michalet-Doreau and OuldBah [9] that takes into account the $\mathrm{CP}$ and NDF (\% DM) contents of the feed in question. Data on DM and CP disappearance for the three straws were analyzed by one-way analysis of variance.

\section{RESULTS AND DISCUSSION}

The chemical composition and in vitro organic matter digestibility value of the two foodstuffs is in Table I. The CP content of narbon vetch grain used in the present study was lower than that of narbon vetch used by Jaques et al. [7], and of common vetch

Table I. Chemical composition and in vitro digestibility of foodstuffs.

\begin{tabular}{lcc}
\hline & \multicolumn{2}{c}{ Narbon vetch } \\
\cline { 2 - 3 } & Grain & Straw \\
\hline $\mathrm{CP}\left(\mathrm{g} \cdot \mathrm{kg}^{-1} \mathrm{DM}\right)$ & $234 \pm 7$ & $74 \pm 2$ \\
$\mathrm{Ash}\left(\mathrm{g} \cdot \mathrm{kg}^{-1} \mathrm{DM}\right)$ & $45 \pm 2$ & $117 \pm 8$ \\
$\mathrm{EE}\left(\mathrm{g} \cdot \mathrm{kg}^{-1} \mathrm{DM}\right)$ & $46 \pm 4$ & $12 \pm 1$ \\
$\mathrm{CF}\left(\mathrm{g} \cdot \mathrm{kg}^{-1} \mathrm{DM}\right)$ & $111 \pm 9$ & $353 \pm 15$ \\
$\mathrm{ADF}\left(\mathrm{g} \cdot \mathrm{kg}^{-1} \mathrm{DM}\right)$ & $124 \pm 11$ & $459 \pm 21$ \\
$\mathrm{NDF}\left(\mathrm{g} \cdot \mathrm{kg}^{-1} \mathrm{DM}\right)$ & $171 \pm 10$ & $575 \pm 20$ \\
$\mathrm{ADL}\left(\mathrm{g} \cdot \mathrm{kg}^{-1} \mathrm{DM}\right)$ & $9 \pm 2$ & $76 \pm 6$ \\
$\mathrm{D}\left(\mathrm{g} \cdot \mathrm{kg}^{-1} \mathrm{DM}\right)$ & $876 \pm 10$ & $448 \pm 10$ \\
$\mathrm{Ca}\left(\mathrm{g} \cdot \mathrm{kg}^{-1} \mathrm{DM}\right.$ & $6.8 \pm 0.2$ & $24.2 \pm 0.8$ \\
$\mathrm{P}\left(\mathrm{g} \cdot \mathrm{kg}^{-1} \mathrm{DM}\right)$ & $4.3 \pm 0.2$ & $1.1 \pm 0.1$ \\
$\mathrm{~K}\left(\mathrm{~g} \cdot \mathrm{kg}^{-1} \mathrm{DM}\right)$ & $11.1 \pm 0.4$ & $17.1 \pm 1.0$ \\
$\mathrm{~S}\left(\mathrm{~g} \cdot \mathrm{kg}^{-1} \mathrm{DM}\right)$ & $4.0 \pm 0.2$ & $2.9 \pm 0.2$ \\
$\mathrm{Mg}\left(\mathrm{g} \cdot \mathrm{kg}^{-1} \mathrm{DM}\right)$ & $1.9 \pm 0.1$ & $3.9 \pm 0.2$ \\
$\mathrm{Fe}\left(\mathrm{g} \cdot \mathrm{kg}^{-1} \mathrm{DM}\right)$ & $1.7 \pm 0.1$ & $19.8 \pm 1.0$ \\
$\mathrm{Cu}\left(\mathrm{mg} \cdot \mathrm{kg}^{-1} \mathrm{DM}\right)$ & $100 \pm 10$ & $150 \pm 15$ \\
$\mathrm{Mn}\left(\mathrm{mg} \cdot \mathrm{kg}^{-1} \mathrm{DM}\right)$ & $350 \pm 20$ & $860 \pm 60$ \\
$\mathrm{Zn}\left(\mathrm{mg} \cdot \mathrm{kg}^{-1} \mathrm{DM}\right)$ & $340 \pm 20$ & $260 \pm 30$ \\
$\mathrm{Co}\left(\mathrm{mg} \cdot \mathrm{kg}^{-1} \mathrm{DM}\right)$ & $66 \pm 6$ & $73 \pm 12$ \\
\hline
\end{tabular}

$\mathrm{CP}$ : crude protein, EE: ether extract, $\mathrm{CF}$ : crude fibre, ADF: acid detergent fibre, NDF: neutral detergent fibre, ADL: acid detergent lignin, $\mathrm{D}$ : in vitro organic matter digestibility.
(Vicia sativa) used by Hadjipanayiotou et al. [5]. On the other hand, its CP content was close to that of bitter vetch (Vicia ervilia) and field beans (Vicia faba) used in the latter studies [5]. Our narbon grain had higher in vitro organic matter digestibility (D), similar ADF, but lower NDF, lignin and CP content than those reported by Jaques et al. [7]. The crude fibre (CF), ash, ADF, NDF, ADL, EE and D value of the narbon vetch straw was close to previously reported values for other leguminous straws [5].

It was planned to offer $400 \mathrm{~g}$ of narbon vetch grain or straw on top of the basic diet, but the consumption of narbon grain during the adaptation period was lower, and the allowance was reduced to $300 \mathrm{~g} \cdot$ head $^{-1}$. Not only the consumption was lower, but also the time spent for consuming the grains was long; indeed, the allowance of narbon beans was available to the animal almost throughout the day. This can be considered as an advantage for maintaining steady $\mathrm{N}$ levels in the rumen of animals offered protein rich supplements consumed at a reasonable daily allowance. On the other hand, in fast growing animals on high concentrate diets offered ad libitum, inclusion of narbon vetch $(10$ or $25 \%)$ in the concentrate mixture resulted in lower growth rate, feed intake and poor feed to gain ratio [4]. The reason of lower intake may be associated with the presence of $\gamma$-glutamic-S-ethenylcysteine that has been isolated and crystallised from aqueous ethanolic extracts of the seeds of narbon bean [3].

Digestibility coefficients of the feeds on test are shown in Table II. Overall, in vivo digestibility of narbon vetch grain was somewhat lower than previously reported values [5] for Cyprus vetch, Bitter vetch, Chickpeas, and Common vetch. The DM and $\mathrm{CP}$ degradability of narbon vetch grain and straw, which are the first ones reported are in Table III.

Based on the findings of the present study it might be concluded that narbon grain 
Table II. Feed intake and digestibility coefficients of narbon vetch grain and straw.

\begin{tabular}{|c|c|c|}
\hline & \multicolumn{2}{|c|}{ Narbon vetch } \\
\hline & Grain & Straw \\
\hline \multicolumn{3}{|c|}{ Feed intake $\left(\mathrm{g} \mathrm{DM} \cdot \mathrm{day}^{-1}\right)$} \\
\hline Concentrate & 356 & 360 \\
\hline Barley hay & 157 & 181 \\
\hline Ingredient on test & $237 \pm 60$ & $332 \pm 24$ \\
\hline \multicolumn{3}{|c|}{ Digestibility (\%) of the ingredient on test } \\
\hline Dry matter & $78.1 \pm 7.2$ & $44.3 \pm 1.1$ \\
\hline Organic matter & $79.9 \pm 7.4$ & $42.1 \pm 2.4$ \\
\hline Crude protein & $75.4 \pm 7.3$ & $47.0 \pm 7.2$ \\
\hline
\end{tabular}

Table III. Dry matter (DM) and crude protein (CP) degradation parameters of narbon vetch grain and straw.

\begin{tabular}{lcrr}
\hline & & \multicolumn{2}{c}{ Narbon vetch } \\
\cline { 3 - 4 } Item & Constant & \multicolumn{1}{c}{ Grain } & \multicolumn{1}{c}{ Straw } \\
\hline DM & a & $29.8 \pm 3.5$ & $7.4 \pm 7.3$ \\
& b & $61.8 \pm 3.3$ & $32.9 \pm 3.2$ \\
& c & $6.3 \pm 0.4$ & $8.4 \pm 1.8$ \\
& ED & $64.1 \pm 2.6$ & $36.4 \pm 3.5$ \\
& & & \\
CP & a & $35.2 \pm 2.0$ & $-13.3 \pm 19.4$ \\
& b & $62.9 \pm 1.7$ & $23.8 \pm 4.6$ \\
& c & $8.9 \pm 3.7$ & $10.1 \pm 2.7$ \\
& ED & $73.8 \pm 4.6$ & $30.8 \pm 2.6$ \\
\hline
\end{tabular}

$\mathrm{a}, \mathrm{b}$ and $\mathrm{c}$ are constants of the exponential equation $\left[\mathrm{P}=\mathrm{a}+\mathrm{b}\left(1-\mathrm{e}^{-\mathrm{ct}}\right)\right]$ where $\mathrm{a}$ is the rapidly degradable fraction, $\mathrm{b}$ the slowly degradable fraction and $\mathrm{c}$ the rate of degradation of fraction $b$ [10]; ED: effective degradability (outflow rate: $0.05 \cdot \mathrm{h}^{-1}$ ). cannot be included, without any processing, in a total diet at levels higher than the ones used in the present study because of low palatability. The degradability of its protein in the rumen is similar to previously reported values for other leguminous grains.

\section{REFERENCES}

[1] AOAC, Association of Official Analytical chemists, Official Methods of Analysis, in: Horwitz W. (Ed.), Washington DC, 1975.

[2] ARC, Agricultural Research Council, The Nutrient Requirements of Ruminant Livestock, Commonwealth Agricultural Bureaux, Slough, UK, 1980.

[3] Eneking D., Delaere I.M., Tate M.E., $\gamma$-glutamate-S-Ethenylcysteine: A dipeptide from Vicia narbonensis, Phytochemistry 48 (1998) 643-645.

[4] Hadjipanayiotou M., Economides S., The effect of partial replacement of soybean meal with either heated or unheated narbon vetch grains on the performance of growing Chios lambs, Annual Rep. Agric. Res. Inst. Nicosia, 1998 68 p. (ISSN 1018-9475).

[5] Hadjipanayiotou M., Economides S., Koumas A., Chemical composition, digestibility and energy content of leguminous grains and straws grown in a Mediterranean region, Ann. Zootech 34 (1985) 23-30.

[6] Hadjipanayiotou M., Koumas A., Georghiades E., Hadjidemetriou D., Studies on degradation and outflow rate of protein supplements in the rumen of dry and lactating Chios ewes and Damascus goats, Anim. Prod. 46 (1988) 243-248.

[7] Jaques S., Dixon R.M., Holmes J.H.G., Narbon beans and field peas as supplements for sheep, Small Rumin. Res. 15 (1994) 39-43.

[8] McDonald P., Edwards R.A., Greenhalgh J.F.D., Animal Nutrition, 2nd ed., Logman, London and New York, 1973, 479 p.

[9] Michalet-Doreau B., Ould-Bah M.Y., Estimation of the extent of bacterial contamination in bag residues and its influence on in sacco measurements of forage nitrogen degradation in the rumen, XVI International Grassland Congress, Nice, France, 1989, pp. 909-910.

[10] Orskov E.R., Protein Nutrition in Ruminants, Academic Press, Inc., London LTD, 1982 $160 \mathrm{p}$.

[11] Tilley J.M.A., Terry R.A., A two-stage technique for the in vitro digestion of forage crops, J. Br. Grassland Soc. 18 (1963) 104-111. 